\title{
Evaluation of the Shelf-Life of Vegetable-Type Soybean Pods
}

\author{
Andréia Cristina Santana ${ }^{1}$, Mercedes Concórdia Carrão-Panizzi ${ }^{2}$, José Marcos Gontijo \\ Mandarino $^{3}$, Rodrigo Santos Leite ${ }^{3}$, Josemeyre Bonifácio da Silva ${ }^{1}$ and Elza Iouko Ida ${ }^{1 *}$ \\ ${ }^{I}$ Departamento de Ciência e Tecnologia de Alimentos; Centro de Ciências Agrárias; Universidade Estadual de \\ Londrina; C. P.: 6001; 6051-970; Londrina - PR. - Brasil. ${ }^{2}$ Empresa Brasileira de Pesquisa Agropecuária; Centro \\ Nacional de Pesquisa de Trigo; Embrapa Trigo; Rod. BR 285; Km 294; C. P.: 451; 99001-970; Passo Fundo - RS - \\ Brasil. ${ }^{3}$ Empresa Brasileira de Pesquisa Agropecuária; Centro Nacional de Pesquisa da Soja; Embrapa Soja; Rod. \\ Carlos João Strass; C. P.: 231; 86001-970; Londrina - PR - Brasil
}

\begin{abstract}
The shelf-life of the vegetable-type soybean pods stored under different conditions was evaluated by chemical characteristics and color. The pods were harvested in the R6 stage and stored either at 30 or $7^{\circ} \mathrm{C}$ for $9 \mathrm{~d}$. After the storage period, the pods were blanched and threshed, and the immature green grains were used for the analysis. The protein content decreased after $6 \mathrm{~d}$ of storage at $7^{\circ} \mathrm{C}$. There was no difference in the lipid content after the storage at 30 and $7^{\circ} \mathrm{C}$ for $9 \mathrm{~d}$. The starch and sucrose contents decreased after the first day of storage at $30^{\circ} \mathrm{C}$. There was no difference in trypsin inhibitor activity until $6 \mathrm{~d}$ of storage at 30 and $7^{\circ} \mathrm{C}$. The green color of the pods that was an indication of the quality that was maintained when stored at $7^{\circ} \mathrm{C}$ during $3 \mathrm{~d}$. To preserve the quality of vegetable-type soybean, pods should be stored at $30^{\circ} \mathrm{C}$ and consumed within $24 \mathrm{~h}$ or stored at $7^{\circ} \mathrm{C}$ for up to $3 d$ of storage.
\end{abstract}

Key words: vegetable-type soybean, sucrose, starch, trypsin inhibitor, color

\section{INTRODUCTION}

Vegetable-type soybean is a food-type soybean harvested when the seeds reach the full pod (R6) stage of the physiological development stage (Fehr and Caviness 1977; Yokomizo and Vello 2000). In the Japanese market, vegetable-type soybeans or their pods can be marketed in two forms, fresh and frozen. The soybeans are consumed in stews, salads or salted snacks. The soybeans are also consumed as an appetizer in which the pods are boiled in salt water, and the green grains are called edamame (Masuda 1991).

The cultivars of vegetable-type soybeans have large grains (seed dry weight greater than 250 $\mathrm{mg} / \mathrm{seed}$ ) with a bright green color, light hilum color, soft texture, mild flavor and sweet flavor (Silva et al. 2010). Quality properties, such as color, texture and grain size, are a function of development time (Mbuvi and Litchfiel 1995). Therefore, it is necessary to adjust the time of harvest for green beans. The pods are bright green in color with gray pubescence and are approximately $5.0 \mathrm{~cm}$ in length and $1.4 \mathrm{~cm}$ in width. Moreover, pods that have two or more bright green grains with a hilum consisting of a buff or yellow color are considered important for the trade (Shanmungasundaram 1991).

The sweetness and mild flavor of vegetable-type soybeans are due to the combination of ascorbic

*Author for correspondence: elida@uel.br 
acid, sucrose, glutamic acid and alanine (Masuda 1991; Silva et al. 2009). Isoflavones, saponins and arginine contribute to the bitterness and sour tastes (Masuda 2004). Together, these aspects of the soybeans provide the unique flavor of the vegetable-type soybeans.

Vegetable-type soybeans have higher nutritional value than other conventional soybean cultivars, including protein content $(12.95 \mathrm{~g} / 100 \mathrm{~g})$, ascorbic acid $(29 \mathrm{mg} / 100 \mathrm{~g}), \beta$-carotene/vitamin A (180 $\mathrm{IU} / 100)$, vitamin B1 $(0.435 \mathrm{mg} / 100 \mathrm{~g})$, vitamin B2 $(0.175 \mathrm{mg} / 100 \mathrm{~g})$ and dietary fiber $(4.2 \mathrm{~g} / 100 \mathrm{~g})$ (Masuda 1991; USDA 2008; Bates et al. 1977).

Studies on the degradation of vegetable-type soybean quality have been limited. Vegetable-type soybeans belong to the vegetable group with a high rate of respiration. Edamame quality is affected by high temperatures at harvest. The contents of sugar, ascorbic acid and amino acids are rapidly reduced (Bates et al. 1977; Chiba 1991).

Due to the short harvest period of vegetable-type soybeans, proper processing and storage are essential to the availability of these soybeans throughout the year (Wang et al. 2010) and to increase the shelf-life of these soybeans. Proper storage temperature can retain the flavor and other sensory attributes that are important for marketing the vegetable-type soybeans. After harvest, the freezing process of grains or pods is essential for the long-term storage. For short-term storage, freezing is not required to maintain the high quality of the soybeans and to minimize the loss of the nutritional and sensory properties ( $\mathrm{Gu}$ et al. 2008). Optimization of the storage temperature is the main factor in preserving all the characteristics of the vegetable-type soybeans.

The objective of this study was to evaluate the shelf-life of pods from the vegetable-type BRS 267 soybean cultivar storage under different conditions by the chemical characteristics and color.

\section{MATERIALS AND METHODS}

The vegetable-type BRS 267 soybean cultivar and its pods were obtained from the breeding program of Embrapa Soybeans (Londrina, South Brazil). The soybeans were harvested in February 2008 at the R6 growth stage (62 d after the flowering).
After the harvest, the soybean pods were either stored at $30^{\circ} \mathrm{C}$ (room temperature) in open plastic trays or at $7^{\circ} \mathrm{C}$ in sealed plastic bags for $9 \mathrm{~d}$.

At the end of the storage period, the pods were blanched in boiling water for 3 min and were then manually threshed. The grains from both the storage conditions were dried in an oven with circulating air (Fanem, $320 \mathrm{SE}$ ) at $45^{\circ} \mathrm{C}$ for $4 \mathrm{~d}$ to complete the drying. After drying, the grains were ground in an analytical mill (Tecnal, TE 631) and were then passed through a sieve $(0.5 \mathrm{~mm})$ to obtain the flours with a 35-mesh particle size. The samples were then placed in plastic and stored at $20^{\circ} \mathrm{C}$ and $40 \%$ humidity until the time of analysis. The moisture, protein, lipid and ash contents were determined according to the method developed by the Institute Adolfo Lutz (2005), and the total carbohydrate content was determined by difference. The analysis of starch was determined by enzymatic hydrolysis according to Richard and Behn (1987). After the material was been cooled, the sugar content was determined by the method of Somogy (1945) and Nelson (1944). The calculation of starch was achieved by converting the percentage of sugar determined by factor 0.9 (Somogyi 1945).

The sucrose content was quantified (Masuda 1996) by ion exchange chromatography (Dionex Bio LC mark), equipped with an amperometric detector, $\mathrm{AgCl}$ electrode (Dionex brand, model ED 50), cell amperometric gold and auto-injector samples. For separation, a CarboPac PA 10 column (internal diameter of $250 \mathrm{~mm} \times 4 \mathrm{~mm}$; particle size of 5 $\mathrm{mm}$ ), adopting the isocratic system with a mobile phase solution consisting of $50 \mathrm{mM} \mathrm{NaOH}$ and a flow rate of $1.0 \mathrm{~mL} / \mathrm{min}$ at $25^{\circ} \mathrm{C}$. The trypsin inhibitor activity was determined according to Kakade et al. (1974) and was expressed as mg/g TI.

Color parameters, such as lightness $\left(\mathrm{L}^{*}\right)$, redgreen component $\left(\mathrm{a}^{*}\right)$ and yellow-blue component (b*) of the pods were determined using a colorimeter (model CR-13; Minolta Co., Japan) with a $10^{\circ}$ angle observer and a D65 illuminant. The experimental design was a randomized block with four replications. The results were subjected to the analysis of variance (ANOVA), and the means were compared by a Tukey's test at 5\% significance. The SAS-Statistical Analysis System (version 8.2; 2001) scientific software package was used. 


\section{RESULTS AND DISCUSSION}

The moisture and protein contents of immature green soybeans did not change until $3 \mathrm{~d}$ after the storage for 30 and $7^{\circ} \mathrm{C}$ (Table 1). After $6 \mathrm{~d}$, the moisture content of the pods decreased with storage at $30^{\circ} \mathrm{C}$. The protein content of the pods decreased after storage at $7^{\circ} \mathrm{C}$ for $3 \mathrm{~d}$, which indicated the influence of temperature on protein level. There was no difference in the lipid content of the pods that were stored at 30 or $7^{\circ} \mathrm{C}$ for $9 \mathrm{~d}$. The ash content of the pods did not differ with temperatures for the first $6 \mathrm{~d}$, but the ash content decreased after $9 \mathrm{~d}$ when the pods were stored at $7^{\circ} \mathrm{C}$.

Table 1 - Chemical composition of the vegetable-type BRS 267 soybean cultivar stored at room temperature $30^{\circ} \mathrm{C}$ and $7^{\circ} \mathrm{C}$ for $9 \mathrm{~d}^{1}$.

\begin{tabular}{ccccccccccc}
\hline Storage & \multicolumn{2}{c}{ Moisture } & \multicolumn{2}{c}{ Protein } & \multicolumn{2}{c}{ Lipids } & \multicolumn{2}{c}{ Ash } & \multicolumn{2}{c}{ Carbohydrate } \\
time (days) & $\mathbf{3 0}^{\mathbf{0}} \mathbf{C}$ & $\mathbf{7}^{\mathbf{o}} \mathbf{C}$ & $\mathbf{3 0}^{\mathbf{o}} \mathbf{C}$ & $\mathbf{7}^{\mathbf{o}} \mathbf{C}$ & $\mathbf{3 0}^{\mathbf{o}} \mathbf{C}$ & $\mathbf{7}^{\mathbf{o}} \mathbf{C}$ & $\mathbf{3 0}^{\mathbf{}} \mathbf{C}$ & $\mathbf{7}^{\mathbf{}} \mathbf{C}$ & $\mathbf{3 0}^{\mathbf{o}} \mathbf{C}$ & $\mathbf{7}^{\mathbf{o}} \mathbf{C}$ \\
\hline 0 & $650.5^{\mathrm{a}}$ & $650.5^{\mathrm{a}}$ & $388.4^{\mathrm{a}}$ & $388.4^{\mathrm{a}}$ & $191.8^{\mathrm{a}}$ & $191.8^{\mathrm{a}}$ & $55.7^{\mathrm{a}}$ & $55.7^{\mathrm{a}}$ & $283.9^{\mathrm{a}}$ & $283.9^{\mathrm{a}}$ \\
1 & $641.1^{\mathrm{a}}$ & $647.0^{\mathrm{a}}$ & $384.3^{\mathrm{a}}$ & $390.3^{\mathrm{a}}$ & $187.3^{\mathrm{a}}$ & $187.9^{\mathrm{a}}$ & $57.3^{\mathrm{a}}$ & $57.0^{\mathrm{a}}$ & $291.6^{\mathrm{a}}$ & $286.8^{\mathrm{a}}$ \\
3 & $633.2^{\mathrm{a}}$ & $633.3^{\mathrm{a}}$ & $385.4^{\mathrm{a}}$ & $378.2^{\mathrm{a}}$ & $188.9^{\mathrm{a}}$ & $180.7^{\mathrm{a}}$ & $57.0^{\mathrm{a}}$ & $55.8^{\mathrm{a}}$ & $288.4^{\mathrm{b}}$ & $309.6^{\mathrm{a}}$ \\
6 & $612.3^{\mathrm{b}}$ & $633.1^{\mathrm{a}}$ & $392.4^{\mathrm{a}}$ & $369.9^{\mathrm{b}}$ & $182.9^{\mathrm{a}}$ & $181.7^{\mathrm{a}}$ & $58.6^{\mathrm{a}}$ & $57.2^{\mathrm{a}}$ & $287.7^{\mathrm{b}}$ & $308.8^{\mathrm{a}}$ \\
9 & $519.9^{\mathrm{b}}$ & $621.3^{\mathrm{a}}$ & $392.7^{\mathrm{a}}$ & $362.2^{\mathrm{b}}$ & $180.2^{\mathrm{a}}$ & $182.1^{\mathrm{a}}$ & $60.3^{\mathrm{a}}$ & $53.1^{\mathrm{b}}$ & $285.7^{\mathrm{b}}$ & $326.6^{\mathrm{a}}$ \\
\hline
\end{tabular}

${ }^{(1)}$ results expressed as $\mathrm{g} \mathrm{kg}^{-1}$ (dry weight); means followed by the same letters in the lines are not different by a Tukey's test at $5 \%$ probability.

The carbohydrate content of the pods was decreased after $3 \mathrm{~d}$ of storage at $30^{\circ} \mathrm{C}$ (Table 1 ). After the first day of storage, the starch and sucrose contents of the pods (Table 2) decreased at $30^{\circ} \mathrm{C}$, but there were no changes in the starch and sucrose contents when the pods were stored at $7^{\circ} \mathrm{C}$. These results suggested that high temperatures could decrease the starch and sugar contents, which have been confirmed by others (Johnstone and Archbold 2007; Gu et al. 2008; Masuda 1996; Liu and Markakis 1987). Chiba (1991) reported that the sugar contents rapidly decreased at high temperatures after the harvest and that free amino acids also decreased in a short period of time.

Table 2 - Starch content, sucrose content and trypsin inhibitor activity of the vegetable-type BRS 267 soybean cultivar stored at room temperature $30^{\circ} \mathrm{C}$ and $7^{\circ} \mathrm{C}$ for $9 \mathrm{~d}^{1}$.

\begin{tabular}{|c|c|c|c|c|c|c|}
\hline \multirow[t]{2}{*}{ Storage time (days) } & \multicolumn{2}{|c|}{ Starch } & \multicolumn{2}{|c|}{ Sucrose } & \multicolumn{2}{|c|}{ Trypsin inhibitor } \\
\hline & $30^{\circ} \mathrm{C}$ & $7^{\circ} \mathrm{C}$ & $30^{\circ} \mathrm{C}$ & $7^{\circ} \mathrm{C}$ & $30^{\circ} \mathrm{C}$ & $7^{\circ} \mathrm{C}$ \\
\hline 0 & $46.6^{\mathrm{a}}$ & $46.6^{\mathrm{a}}$ & $45.2^{\mathrm{a}}$ & $45.2^{\mathrm{a}}$ & $21.65^{\mathrm{a}}$ & $21.65^{\mathrm{a}}$ \\
\hline 1 & $37.3^{\mathrm{b}}$ & $42.5^{\mathrm{a}}$ & $35.5^{\mathrm{b}}$ & $42.2^{\mathrm{a}}$ & $21.54^{\mathrm{a}}$ & $21.81^{\mathrm{a}}$ \\
\hline 3 & $25.6^{\mathrm{b}}$ & $42.7^{\mathrm{a}}$ & $32.7^{\mathrm{b}}$ & $41.6^{\mathrm{a}}$ & $20.24^{\mathrm{a}}$ & $21.18^{\mathrm{a}}$ \\
\hline 6 & $14.3^{b}$ & $40^{\mathrm{a}}$ & $30.2^{\mathrm{b}}$ & $40.9^{\mathrm{a}}$ & $19.85^{\mathrm{a}}$ & $20.36^{\mathrm{a}}$ \\
\hline 9 & $8.3^{\mathrm{b}}$ & $21.2^{\mathrm{a}}$ & $30.1^{\mathrm{b}}$ & $43^{\mathrm{a}}$ & $20.43^{\mathrm{a}}$ & $17.77^{\mathrm{b}}$ \\
\hline
\end{tabular}

(1) results expressed as $\mathrm{g} \mathrm{kg}^{-1}$ (dry weight) for starch and sucrose contents and $\mathrm{mg}$ IT/g (dry weight) for trypsin inhibitor activity; means followed by the same letters in the lines do not differ by a Tukey's test at $5 \%$ probability.

There was no difference in trypsin inhibitor activity after $6 \mathrm{~d}$ of storage at 30 and $7^{\circ} \mathrm{C}$. After 9 $\mathrm{d}$ of storage, the trypsin inhibitor activity decreased when the pods were stored at $7^{\circ} \mathrm{C}$ (Table 2).

The $\mathrm{L}^{*}$ values, which measured the luminosity of the pods were lower after $3 \mathrm{~d}$ of storage at $7^{\circ} \mathrm{C}$ (Table 3) suggesting that the time and refrigeration could darken the pod color. However, the $a^{*}$ value was higher when the pods were stored at $7^{\circ} \mathrm{C}$, resulting in a greener color. There was no difference in the $b^{*}$ values after $2 \mathrm{~d}$ of storage.
However, the pods had a bluer color when stored at $7^{\circ} \mathrm{C}$ for $3 \mathrm{~d}$. Together, these results demonstrated that the storage at $7^{\circ} \mathrm{C}$ preserved pod color for the first $3 \mathrm{~d}$ of storage. According to Johnstone and Archbold (2007), vegetable-type soybeans may have potential as a healthy snack food or appetizer. They suggested that for soybeans to be utilized as appetizers, the processing should be as follows: blanching of the pod; frozen for storage and shipping; and thawed on the display shelf prior to purchase. They also evaluated the pod quality and beneficial health 
traits of the vegetable-type soybeans after blanching and freezing and found that the pod color was lighter and more yellowish-green after blanching and freezing. Johnstone and Archbold (2007) also reported that the duration of cold storage had no clear effect, and that sucrose levels decreased after cold storage. Their results contradicted the results obtained in this study where glucose increased during the cold storage. Johnstone and Archbold (2007) concluded that the blanched and frozen vegetable-type soybean grains when thawed retained acceptable overall quality for at least $7 \mathrm{~d}$ in cold storage.

Table 3 - Color parameters of pods from the vegetable-type BRS 267 soybean cultivar stored at room temperature $30^{\circ} \mathrm{C}$ and $7^{\circ} \mathrm{C}$ for $9 \mathrm{~d}^{1}$.

\begin{tabular}{|c|c|c|c|c|c|c|}
\hline \multirow{2}{*}{ Storage time (days) } & \multicolumn{2}{|r|}{$\mathrm{L}^{*}$} & \multicolumn{2}{|r|}{$a^{*}$} & \multicolumn{2}{|c|}{$\mathrm{b}^{*}$} \\
\hline & $30^{\circ} \mathrm{C}$ & $7^{\circ} \mathrm{C}$ & $30^{\circ} \mathrm{C}$ & $7^{\circ} \mathrm{C}$ & $30^{\circ} \mathrm{C}$ & $7^{\circ} \mathrm{C}$ \\
\hline 0 & $19.7^{\mathrm{a}}$ & $19.7^{\mathrm{a}}$ & $-7.9^{a}$ & $-7.9^{\mathrm{a}}$ & $20.2^{\mathrm{a}}$ & $20.2^{\mathrm{a}}$ \\
\hline 1 & $19.5^{\mathrm{a}}$ & $19.6^{\mathrm{a}}$ & $-4.5^{b}$ & $-7.5^{\mathrm{a}}$ & $19.8^{\mathrm{a}}$ & $20.3^{\mathrm{a}}$ \\
\hline 3 & $26.5^{\mathrm{a}}$ & $21.9^{\mathrm{b}}$ & $-4.2^{\mathrm{b}}$ & $-5.4^{\mathrm{a}}$ & $22.3^{\mathrm{a}}$ & $19.1^{\mathrm{b}}$ \\
\hline 6 & $31.3^{\mathrm{a}}$ & $22.9^{\mathrm{b}}$ & $-1.4^{\mathrm{b}}$ & $-4.9^{a}$ & $27.3^{\mathrm{a}}$ & $20.7^{\mathrm{b}}$ \\
\hline 9 & $35.9^{\mathrm{a}}$ & $23.8^{\mathrm{b}}$ & $-1.0^{\mathrm{b}}$ & $-4.9^{a}$ & $30.8^{\mathrm{a}}$ & $24.7^{\mathrm{b}}$ \\
\hline
\end{tabular}

(1) means followed by the same letter in the line do not differ by a Tukey's test at $5 \%$ probability (average values of five replicates). The $\mathrm{L}^{*}$ value indicates white $(100)$ or black $(0)$, and the $\mathrm{a}^{*}$ value indicates red $(+)$ or green $(-)$. The $\mathrm{b}^{*}$ value indicates yellow (+) or blue (-). Maximal values for $\mathrm{a}^{*}$ and $\mathrm{b}^{*}$ are between 100 and -100 , respectively.

The importance of cooling and/or freezing vegetable-type soybean pods after the harvest to maintain high quality has been previously described by Masuda et al. (1989). Compared to fresh edamame, the grains from the frozen pods had higher concentrations of sucrose $(1.7 \%$ versus $1.1 \%$, respectively) and amino acids (e.g., alanine; $0.3 \mathrm{~g} \mathrm{~kg}^{-1}$ versus $0.16 \mathrm{~g} \mathrm{~kg}^{-1}$, respectively).

For a shorter time of storage, vegetable-type soybean pods must be properly harvested, blanched and stored at $30^{\circ} \mathrm{C}$ in open plastic trays and should be consumed within $24 \mathrm{~h}$. For a longer time of storage, the pods must also be properly harvested, blanched and stored at $7{ }^{\circ} \mathrm{C}$ in closed plastic bags and should be consumed within $72 \mathrm{~h}$ to preserve the soybean quality characteristics (Lee and Hwang 1998), including the appearance and sweetness.

\section{CONCLUSIONS}

The protein, starch and sucrose contents of the vegetable-type soybean pods decreased during the storage for $9 \mathrm{~d}$ at 30 and $7^{\circ} \mathrm{C}$. The color was preserved during the first $3 \mathrm{~d}$ of storage at $7^{\circ} \mathrm{C}$. Therefore, for guaranteed consumption in a short period of time $(24 \mathrm{~h})$, the vegetable-type soybean pods could be stored at $30^{\circ} \mathrm{C}$ in open plastic trays. For the consumption after a longer period of time $(72 \mathrm{~h})$, the pods should be stored at $7^{\circ} \mathrm{C}$ in closed plastic bags. These conditions will preserve the better qualities of the vegetable-type soybeans.

\section{REFERENCES}

Bates RP, Knapp EW, Araujo PE. Protein quality of Green mature, dry matter and sprout soybeans. $J$. Food Sci. 1977; 42 (1):271-272.

Chiba Y. Postharvest processing, marketing and quality degradation of vegetable soybean in Japan. In: Workshop [on] Vegetable Soybean. Proceedings.Taiwan: Council of Agriculture; 1991. p. 109-112.

Fehr WR, Caviness CE. Stages of soybean development. Ames: (Special Report 80). Cooperative Extension Service; 1977. p. 11.

Gu L, Ma Y, Sun DW, Wang P. Effects of controlled freezing-point storage at $0{ }^{0} \mathrm{C}$ on quality of green bean as compared with cold and room temperature storages. J. Food Eng. 2008; 86 (1):25-29.

Instituto Adolfo Lutz. Métodos físico-químicos para análise de alimentos. Brasília: Instituto Adolfo Lutz, IV edição, p. 1018; 2003.

Johnstone C, Archbold DD. Handling and storage effects on quality and health-beneficial compounds of ready to eat edamame. In: ISHS Acta Horticulturae; 2007. II International Symposium on Human Health Effects of Fruits and Vegetables; 2007: FAVHEALTH. 
Kakade ML, Rackis JJ, McGhee JE, Pushi G. Determination of trypsin inhibitor activity of soy products. A collaborative analysis of an improved procedure. Cereal Chem. 1974; 51: 376 - 379.

Lee JD, Hwang YH. Quality evaluation for vegetable use in local soybean cultivars with various seed coat color. Korean J. Crop Sci. 1998; 43:83-88.

Liu K, Markakis P. Effect of maturity and processing on the thrypsin inhibitor and oligossacharides of soybeans. J. Food Sci. 1987; 52(1):222-223.

Masuda R. Quality Requeriment and Improvement of Vegetable Soybean. Shanmungasundaram, S. (Ed.). Vegetable Soybean: Research Needs for Production and Quality Improvement. Proceedings of Workshop, Kenting, Taiwan. Asian Vegetable Research and Development Center; 1991. Publication $n^{\circ}$ 91-346: 92-102.

Masuda R. The strategy for sweetness increase of vegetable soybean: maltose, another sugar in boiled seeds. In: VII World Soybean Research Conference, IV International Soybean Processing and Utilization Conference, III Brazilian Congress, 2004 Foz Do Iguaçu. Proceedings...Londrina: Embrapa Soja, 2004. p. 839-844. (Embrapa Soja. Documentos, 228).

Masuda R, Kaneko K, Yamashita I. Sugar and cyclitol determination in vegetables by HPLC using post column fluorescent derivatization. J. Food Sci. 1996; 61:1186-1190.

Masuda R, Hashizume K, Kanelo K. Effect of holding time before freezing on the constituents and the flavor of frozen green soybeans. Nihon Shokuhin Kogyo Gakkaishi. 1989; 35:763-70.

Mbuvi SW, Litchfield JB. Green soybeans as vegetable: comparing green soybeans with green peas and lima beans and maximized harvest time determinations using mathematical modeling. J. Veg. Crop Prod. 1995; 1:1-99.

Nelson NA. Photometric adaptation of the Somogy method for the determination of glucose. J. Biol. Chem. 1944; 156: 375-380.
Kakade M, Rackis JJ, Mcghee JE, Puski G. Determination of trypsin inhibitor activity of soy produts: a collaboratie analysis of an improved prodedure. Cereal Chem. 1974; 51:376-383.

Yokomizo GK, Vello NA. Physiological quality in seeds obtained by topcrosses between vegetable soybean and grain type. Braz. Arch. Biol. Technol. 2000; 43(5):469-473.

Rickard JE, Behn KR. Evaluation of acid and enzyme hydrolitic methods for determination of cassava starch. J. Sci. Food Agr. 1987, 41:373-379.

Shanmungasundaram, S. Vegetable Soybean: research needs for production and quality improvement. Proceedings of Workshop, Kenting, Taiwan. Asian Vegetable Research and Development Center, Publication no 91-346. 1991; 92-102.

Silva JB, Carrão-Panizzi MC, Prudencio SH. Chemical and physical composition of grain- type and food- type soybean for food processing. Pesq. Agrop. Bras. 2009; 44 (7):777-784.

Silva JB, Carrão-Panizzi MC, Felberg I, Lee S Y, Prudencio SH. Relationships among sensory analysis, isoflavone and hexanal contents of soymilk powder. Braz. Arch. Biol. Technol. 2010; 53 (5):1197-1204.

Somogy M. Determination of blood sugar. $J$. Biol.Chem. 1945; 160:69-73.

USDA, Department Of Agriculture of The United States. National Nutrient Database For Standard Reference Release 21 (2008).

Wang YJ, Saldivar X, Mauromoustakos A. Effects of blaching and storage conditions on soluble sugar contents in vegetable soybean. J. F. Sci. Tech. 2010; 43:1368-1372. 


\section{Página Em}

Branco 